\title{
MODEL PERLINDUNGAN SOSIAL BAGI PENYANDANG DISABILITAS DI KABUPATEN CIANJUR DIKAJI DALAM PERSPEKTIF HAK ASASI MANUSIA
}

\section{MODEL FOR SOCIAL PROTECTION FOR PEOPLE WITH DISABILITIES IN CIANJUR DISTRICT IN PERSPECTIVE OF HUMAN RIGHTS}

Tanti Kirana Utami

\author{
Program Studi Hukum, Fakultas Hukum, \\ Universitas Suryakancana . \\ Korespondensi : Tanti Kirana Utami, Tel. 082128487788 \\ e-mail : kireinatanti78@gmail.com
}

\begin{abstract}
Jurnal Living Law, Vol. 11, No. 2 , 2019 hlm. 131139

Abstract : Law Number 39 of 1999 concerning Human Rights regulates the obligations of the State in protecting each of its citizens, including the respect, protection and fulfillment of the rights of persons with disabilities. Persons with disabilities should get the same opportunity in developing themselves through independence as human beings with dignity. Based on the foregoing it is very important to conduct research on persons with disabilities to find out the objective conditions of persons with disabilities in Cianjur district and to find out policies and programs for social protection activities for persons with disabilities. The research method used is normative juridical with descriptive analytical research specifications. The results showed that the condition of persons with disabilities in Cianjur Regency was caused due to birth or illness with various disabilities spread in several districts and social protection for persons with disabilities in Cianjur regency carried out in the form of providing various facilities and social security in stages. The conclusion of this study is the data of persons with disabilities in Cianjur Regency already included including social protection provided by the government. For this reason, it is expected that various facilities and social security will be improved and local regulations made.
\end{abstract}

Keywords : Social Protection, Human Rights, Disability.

\begin{abstract}
Abstrak : Undang-Undang Nomor 39 Tahun 1999 tentang Hak Asasi Manusia mengatur tentang kewajiban Negara dalam melindungi setiap warga negaranya termasuk juga untuk melakukan Penghormatan, Pelindungan, dan Pemenuhan hak Penyandang Disabilitas. Penyandang Disabilitas seharusnya mendapatkan kesempatan yang sama dalam upaya mengembangkan dirinya melalui kemandirian sebagai manusia yang bermartabat. Berdasarkan hal tersebut di atas sangat penting untuk dilakukan penelitian mengenai penyandang disabilitas untuk mengetahui kondisi obyektif penyandang disabilitas di kabupaten cianjur dan untuk mengetahui kebijakan dan program kegiatan perlindungan sosial bagi penyandang disabilitas. Metode penelitian yang digunakan adalah yuridis normatif dengan spesifikasi penelitian deskriptif analitis. Hasil penelitian menunjukan bahwa kondisi penyandang disabilitas di Kabupaten Cianjur disebabkan karena sejak lahir atau sakit dengan beragam disabilitas yang tersebar di beberapa kecamatan dan perlindungan sosial bagi penyandang disabilitas di kabupaten Cianjur dilakukan dalam bentuk pemberian berbagai fasilitas dan jaminan sosial secara bertahap. Kesimpulan dari penelitian ini adalah data penyandang disabilitas di Kabupaten Cianjur sudah ada termasuk perlindungan sosial yang diberikan oleh pemerintah. Untuk itu, diharapkan berbagai fasilitas dan jaminan sosial semakin ditingkatkan serta dibuatnya peraturan daerah.
\end{abstract}

Kata Kunci : Perlindungan Sosial, HAM, Disabilitas. 


\section{PENDAHULUAN}

Negara Republik Indonesia yang berdasarkan Pancasila dan Undang-Undang Dasar Negara Republik Indonesia Tahun 1945 menghormati dan menjunjung tinggi harkat dan martabat manusia. Hak asasi manusia sebagai hak dasar yang secara kodrati melekat pada diri manusia bersifat universal, perlu dilindungi, dihormati, dan dipertahankan, sehingga Pelindungan dan hak asasi manusia terhadap kelompok rentan, khususnya Penyandang Disabilitas. ${ }^{1}$

Penghormatan, Pelindungan, dan Pemenuhan hak Penyandang Disabilitas merupakan kewajiban Negara diatur dalam Undang-Undang Nomor 39 Tahun 1999 tentang Hak Asasi Manusia, sehingga masyarakat mempunyai tanggung jawab untuk menghormati hak Penyandang Disabilitas. Penyandang Disabilitas selama ini mengalami banyak Diskriminasi yang berakibat belum terpenuhinya pelaksanaan hak Penyandang Disabilitas.

Selama ini, pengaturan mengenai Penyandang Disabilitas diatur dalam Undang-Undang Nomor 4 Tahun 1997 tentang Penyandang Cacat, tetapi pengaturan ini belum berperspektif hak asasi manusia. Materi muatan dalam Undang-Undang Nomor 4 Tahun 1997 tentang Penyandang Cacat lebih bersifat belas kasihan (charity based) dan Pemenuhan hak Penyandang Disabilitas masih dinilai sebagai masalah sosial yang kebijakan Pemenuhan haknya baru bersifat jaminan sosial, rehabilitasi sosial, bantuan sosial, dan peningkatan kesejahteraan sosial. Penyandang Disabilitas seharusnya mendapatkan kesempatan yang sama dalam upaya mengembangkan dirinya melalui kemandirian sebagai manusia yang bermartabat.

Beberapa kecamatan di Kabupaten cianjur banyak terdapat penyandang disabilitas yang masuk kategori miskin yaitu usia 15-44 tahun yang cukup banyak yaitu 149-226 orang, antara lain di

\footnotetext{
1 Penjelasan umum UU No,8 tahun 2016 tentang penyandang disabilitas
}

kecamatan cianjur, cugenang, karang tengah cibeber, cikalong kulon dan cidaun. ${ }^{2}$ Berdasarkan hal tersebut, sangat penting diakukan penelitian mengenai pelaksanaan pemenuhan hak kesejahteraan sosial penyandang disabilitas di Kabupaten Cianjur .

Adapun permasalahan yang akan diteliti adalah sebagai berikut:

1. Bagaimana kondisi obyektif penyandang disabilitas di kabupaten cianjur?

2. Bagaimana perlindungan sosial bagi penyandang disabilitas di kabupaten cianjur?

Secara khusus penelitian ini bertujuan:

1. Menggambarkan kondisi obyektif penyandang disabilitas di Kabupaten Cianjur.

2. Menggambarkan pemenuhan hak kesejahteraan sosial penyandang disabilitas di kabupaten cianjur.

\section{METODE PENELITIAN}

Metode penelitian yang digunakan adalah metode yuridis normative dengan spesifikasi penelitian deskriptif analisis bertujuan untuk mengungkapkan secara sistematis, metodologis, dan konsisten dengan mengadakan analisis dan konstruksi. $^{3}$

Penelitian ini dilaksanakan dengan cara:

\section{Metode Pendekatan}

Dalam penelitian ini memakai metode pendekatan Yuridis Normatif, penelitian ini dapat digunakan untuk mencari asas hukum, teori hukum dan sistem hukum, terutama dalam hal penemuan dan pembentukan asas-asas

\footnotetext{
2 Arvian triantoro, menuju sinergitas penanggulangan kemiskina terpadu jawa barat 2018-2023, makalah disampaikan dalam kegiatan workshop penanggulangan kemiskinan , cianjur, 7 agustus 2018

3 Soerjono Soekanto dan Sri Mamudji, Penelitian Hukum Normatif, Suatu Tujuan Singkat, Cetakan VI, Raja Gerapindo Persada, Jakarta, 2001, hlm. 1
} 
hukum baru, pendekatan hukum baru dari sistem hukum nasional. ${ }^{4}$

\section{Jenis dan Sumber Data}

Penelitian ini dilakukan guna memperoleh data yang akurat maka dilakukan melalui 2 (dua) tahapan besar sebagai berikut:

a) Penelitian kepustakaan (library research) yaitu dengan mengumpulkan dan mempelajari bahan hukum primer, sekunder dan tersier yang berkaitan dengan topik penelitian. ${ }^{5}$

b) Penelitian lapangan (field research), tujuannya mencari data-data lapangan yang berkaitan dengan materi penelitian dan berfungsi sebagai pendukung data sekunder.

\section{Prosedur Pengumpulan Data}

Untuk pengumpulan data melalui 2 (dua) cara diantaranya :

1) Penelitian Awal (Pra Survey), yaitu pengambilan data awal di instansi/lembaga terkait, misalnya Dinas Sosial Kabupaten Cianjur untuk memudahkan langkah pengumpulan data selanjutnya;

2) Studi Pustaka (Library research), yakni melalui berbagai dokumen dan bahan-bahan pustaka yang berkaitan dengan penelitian ini.

\section{Teknik Pengecekan Validasi Data}

Disamping teknik diatas pengecekan keabsahan data juga dilakukan melalui teknik pemeriksaan triangulasi, khususnya triangulasi sumber, Patton dalam bukunya dengan judul 'Qualitative Data Analysis; A Sourcebook

\footnotetext{
4 Sunaryati, Penelitian Hukum di Indonesia Pada Abad ke 20, Alumni, Bandung, 1994, hlm.105; penelitian yang bersifat yuridis normative, dapat dibedakan menjadi penelitian monodisipliner dan interdisipliner.

5 Dedi Mulyadi, Kebijakan Legislasi Tentang Sanksi Pidana Pemilu Legislatif di Indonesia Dalam Perspektif Demokrasi, Disertasi, Program Doktor Ilmu Hukum Program Pascasarjana Universitas Katolik Parahiyangan Bandung, 2011, hlm. 56; lihat pula Wila Chandra Wila Supardi, Metode Penelitian, Materi Kuliah Metode Penelitian Program Pascasarjana Doktor Ilmu Hukum Universitas Katolok Parahyangan, Bandung, 2009, hlm. 17
}

of New Methods', sebagaimana dikutip oleh Lexi J. Moleng menyebutkan bahwa triangulasi dengan sumber berarti membandingkan dan mengecek balik tingkat kepercayaan suatu informasi yang diperoleh melalui waktu dan alat yang berbeda dalam metode kualitatif. 6

\section{Analisis Data}

Pengertian analisis di sini dimaksudkan sebagai interpretasi secara logis, sistimatis dan konsisten dimana dilakukan penelaahan data yang lebih rinci dan mendalam. Dari data yang berhasil dikumpulkan.

\section{PEMBAHASAN}

\section{KONDISI PENYANDANG DISABILITAS DI KABUPATEN CIANJUR DIKAJI DALAM PERSPEKTIF HAM}

Manusia adalah makhluk ciptaan Allah SWT yang mempunyai kedudukan yang sama dimuka bumi. Setiap manusia mempunyai harkat dan martabat (dignity) yang melekat pada kemanusiaannya. Dengan keyakinan akan kuasa Tuhan sebagai Pencipta, kondisi disabilitas yang dialami sebagian anak manusia adalah fakta ilahi. Kondisi ini tidak boleh menjadi penyebab hilangnya harkat dan martabat penyandang disabilitas, atau menjadi alasan untuk tidak mensejajarkan mereka dengan warga lain dalam segala bidang kehidupan, baik politik, ekonomi, sosial dan budaya. $^{7}$

Indonesia adalah Negara hukum, juga menganut prinsip Negara kesejahteraan yang mana Negara dapat menggunakan hukum sebagai salah satu sarana untuk mengatur dan menyelenggarakan serta menjamin kesejahteraan rakyatnya. ${ }^{8} \mathrm{Di}$

\footnotetext{
6 Lexy J. Moleong, Metodologi Penelitian Kualitatif, Remaja Rosda Karya, Bandung, 2001, hlm. 178

7 Rahayu Repindowaty Harahap dan Bustanuddin, Perlindungan Hukum Terhadap Penyandang Disabilitas Menurut Convention On The Rights of Persons With Disabilities (CRPD) Jurnal Inovatif, Volume VIII Nomor I Januari 2015, hlm.17 dalam 8 Ahmad hunaeny Zulkarnaen dan Tanti Kirana Utami, Perlindungan Hukum terhadap Pekerja
} 
Indonesia, jaminan Hak Asasi Manusia tercantum dalam Pasal 28A-28J UndangUndang Dasar Negara Republik Indonesia 1945 (selanjutnya disebut UUD NRI Tahun 1945). ${ }^{9}$ Pencantuman hak asasi manusia dalam UUD NRI Tahun 1945, secara resmi telah menjadikannya sebagai hak konstitusional setiap warga negara atau "constitutional right".10 Henny mengatakan bahwa Human rights is defined as the fundamental rights of the human person. ${ }^{11}$ Dengan adanya hak konstitusional, setiap warga negara memiliki jaminan konstitusional atas setiap hak-haknya yang termuat dalam UUD RI Tahun 1945. Jaminan tersebut dapat berupa pengejawantahan hak konstitusonal ke dalam undang-undang atau penyediaan ruang gugatan konstitusional ke Mahkamah Konstitusi jika ada pelanggaran terhadap hak-hak warga negara. ${ }^{12}$

Pengertian hak asasi manusia dalam bahasa Arab disebut huququl insan, atau human rights (Inggris), droits de l'homme (Perancis), menschenrechte (Belanda/Jerman), derechos humanos (Spanyol), direitos humanos (Brazil),

dalam pelaksanaan Hubungan Industrial, PJIH vol. 3 nomor 2 tahun 2016, hlm. 408.

9 Jimly Asshiddiqie, Pengantar Ilmu Hukum Tata Negara Jilid 2, Sekretaris Jenderal dan Kepaniteraan Mahkamah Konstitusi, Jakarta, 2006, hlm. 105 dalam Jazim Hamidi, Perlindungan Hukum terhadap Disabilitas dalam Memenuhi Hak Mendapatkan Pendidikan dan Pekerjaan Jurnal Hukum, IUS QUIA IUSTUM NO. 4 VOL. 23 OKTOBER 2016, hlm. 654

10 Zulkarnain Ridlwan, "Perlindungan Hak-hak Konstitusional Penyandang Disabilitas (Rights of Persons with Disabilities)", dimuat dalam Fiat Justitia Jurnal Ilmu Hukum, Volume 7 No. 2, Mei Agustus 2013, hlm. 231 dan 233 lihat Jazim Hamidi, Perlindungan Hukum terhadap Disabilitas dalam Memenuhi Hak Mendapatkan Pendidikan dan Pekerjaan Jurnal Hukum, IUS QUIA IUSTUM NO. 4 VOL. 23 OKTOBER 2016hlm. 654.

11 Henny nuraeny dan Tanti Kirana Utami, Legal Protection Against Children Who Are Victims of Human Trafficking In Cianjur District Studied By Human Rights Perspective, Jurnal Dinamika Hukum ,Vol. 15 No. 2, May 2015, hlm. 174.

12 Jazim Hamidi, Perlindungan Hukum terhadap Disabilitas dalam Memenuhi Hak Mendapatkan Pendidikan dan Pekerjaan Jurnal Hukum, IUS QUIA IUSTUM NO. 4 VOL. 23 OKTOBER 2016hlm. 654. dirittiumani (Itali) dan sebagainya. ${ }^{13}$ Indonesia menganut asas dan konsep Pancasila yang terkandung dalam Pembukaan UndangUndang Dasar 1945.14 Di dalam Pasal 1 angka 1 UU No. 39 Tahun 1999 tentang Hak Asasi Manusia, dijelaskan bahwa :

"Hak asasi manusia adalah seperangkat hak yang melekat pada hakekat dan keberadaan manusia sebagai makhluk Tuhan Yang Maha Esa dan merupakan anugrah-Nya yang wajib dihormati, dijunjung tinggi dan dilindungi oleh Negara, hukum, pemerintah, dan setiap orang demi kehormatan serta perlindungan harkat dan martabat manusia". ${ }^{15}$

Kategori/Klasifikasi HAM menurut UU No. 39 Tahun 1999 adalah :

1. Hak untuk hidup

2. Hak berkeluarga dan melanjutkan keturunan

3. Hak mengembangkan diri

4. Hak memperoleh keadilan

5. Hak atas kebebasan pribadi

6. Hak atas rasa aman

7. Hak atas kesejahteraan

8. Hak turut serta dalam pemerintahan

Pasal 1 angka 1 UU No. 8 Tahun 2016 menjelaskan bahwa Penyandang Disabilitas adalah setiap orang yang mengalami keterbatasan fisik, intelektual, mental, dan/atau sensorik dalam jangka waktu lama yang dalam berinteraksi dengan lingkungan dapat mengalami hambatan dan kesulitan untuk berpartisipasi secara penuh dan efektif dengan warga negara lainnya berdasarkan kesamaan hak.

Kaum difabel rentan mendapat perlakuan diskriminasi dari pihak lain dikarenakan keterbatasan fisik dan psikhis. Dalam Pasal 1 huruf C UU No. 39 tahun 1999 tentang HAM dijelaskan bahwa Diskriminasi adalah setiap pembatasan, pelecehan, atau pengucilan yang langsung

13 Majda El Muhtaj, 2008, Dimensi-Dimensi HAM Mengurai Hak Ekonomi, Sosial, dan Budaya, Jakarta, Raja Grafindo Persadaa, hlm. 17 - 18.

${ }^{14}$ Abdul Wahid, hak atas informasi atau kebohongan public, Jurnal Konstitusi, Volume 6, Nomor 3, September 2009, Jakarta, Mahkamah Konstitusi, hlm 3

15 UU No. 39 Tahun 1999 tentang HAM 
ataupun tak langsung didasarkan pada pembedaan manusia atas dasar agama, suku, ras, etnik, kelompok, golongan, status sosial, status ekomomi, jenis kelamin, bahasa, keyakinan politik. yang berakibat pengurangan, penyimpangan atau penghapusan pengakuan, pelaksanaan atau penggunaan hak asasi manusia dan kebebasan dasar dalam kehidupan baik individual maupun kolektif dalam bidang politik, ekonomi,hukum, sosial, budaya. dan aspek kehidupan lainnya.

Undang-Undang Nomor 19 Tahun 2011 tentang Pengesahan Convention on the Rights of Persons with Disabilities (Konvensi Hak-hak Penyandang Disabilitas) tanggal 10 November 2011 menunjukkan komitmen dan kesungguhan Pemerintah Indonesia untuk menghormati, melindungi, dan memenuhi hak Penyandang Disabilitas yang pada akhirnya diharapkan dapat meningkatkan kesejahteraan Penyandang Disabilitas.

Kondisi penyandang disabilitas di Kabupaten Cianjur disebabkan karena sejak lahir, kecelakaan dan sakit dengan beragam disabilitas yang tersebar di beberapa kecamatan, misalnya kecamatan karangtengah, kecamatan campaka, kecamatan cianjur, kecamatan cikalongkulon, kecamatan mande, kecamatan cilaku, kecamatan warungkondang, kecamatan ciranjang, kecamatan gekbrong, kecamatan sukaresmi, kecamatan pacet, kecamatan bojong picung, kecamatan cipanas, kecamatan cibeber, kecamatan tanggeung, kecamatan sukanagara, kecamatan kadupandak.

Pendidikan penyandang disabilitas di Kabupaten Cianjur bervariatif ada yang belum sekolah, lulusan SD, SMP, SMU, studi lanjut ke perguruan tinggi, baik laki-laki maupun perempuan. Saat ini, penyandang disabilitas ada yang berstatus pelajar, mahasiswa, bekerja dan tidak bekerja. Ragam disabilitas meliputi tuna daksa, tuna rungu, down syndrome, tuna wicara, tuna netra dan autis.

\section{PERLINDUNGAN SOSIAL BAGI PENYANDANG DISABILITAS DI KABUPATEN CIANJUR.}

Indonesia menjamin kelangsungan hidup setiap warga negara, termasuk para penyandang disabilitas yang mempunyai kedudukan hukum dan memiliki hak asasi manusia yang sama sebagai Warga Negara Indonesia dan sebagai bagian yang tidak terpisahkan dari warga negara dan masyarakat Indonesia merupakan amanah dan karunia Tuhan Yang Maha Esa, untuk hidup maju dan berkembang secara adil dan bermartabat.16 Selanjutnya, sebagian besar penyandang disabilitas di Indonesia hidup dalam kondisi rentan, terbelakang, dan/atau miskin disebabkan masih adanya pembatasan, hambatan, kesulitan, dan pengurangan atau penghilangan hak penyandang disabilitas. ${ }^{17}$

Pelaksanaan dan Pemenuhan hak Penyandang Disabilitas berasaskan:

a. Penghormatan terhadap martabat;

b. otonomi individu;

c. tanpa Diskriminasi;

d. partisipasi penuh;

e. keragaman manusia dan kemanusiaan;

f. Kesamaan Kesempatan;

g. kesetaraan;

h. Aksesibilitas;

i. kapasitas yang terus berkembang dan identitas anak;

j. inklusif; dan

k. perlakuan khusus dan Pelindungan lebih. ${ }^{18}$

Yang dimaksud dengan "asas Penghormatan terhadap martabat" adalah pengakuan terhadap harga diri Penyandang Disabilitas yang harus dilindungi, dihormati, dan ditegakkan. "asas otonomi individu" adalah hak setiap Penyandang Disabilitas untuk bertindak atau tidak bertindak dan bertanggung jawab atas pilihan tindakannya tersebut.

Asas partisipasi penuh adalah Penyandang Disabiltas berperan serta secara aktif dalam segala aspek kehidupan sebagai warga negara. "asas keragaman

\footnotetext{
16 Konsideran menimbang UU No. 8 Tahun 2016 tentang Penyandang Disabilitas.

17 Ibid

18 Pasal 2 UU No. 8 tahun 2016 tentang penyandang disabilitas
} 
manusia dan kemanusiaan" adalah Penghormatan dan penerimaan perbedaan terhadap Penyandang Disabilitas sebagai bagian dari keragaman manusia dan kemanusiaan . "asas kesetaraan" adalah kondisi di berbagai sistem dalam masyarakat dan lingkungan, seperti pelayanan, kegiatan, informasi, dan dokumentasi yang dibuat dapat mengakomodasi semua orang termasuk Penyandang Disabilitas.

Pasal 5 UU no. 8 Tahun 2016 menjelaskan bahwa Penyandang Disabilitas memiliki hak:

a. hidup;

b. bebas dari stigma;

c. privasi;

d. keadilan dan perlindungan hukum;

e. pendidikan;

f. pekerjaan, kewirausahaan, dan koperasi;

g. kesehatan;

h. politik;

i. keagamaan;

j. keolahragaan;

k. kebudayaan dan pariwisata;

l. kesejahteraan sosial;

m. Aksesibilitas;

n. Pelayanan Publik;

o. Pelindungan dari bencana;

p. habilitasi dan rehabilitasi;

q. Konsesi;

r. pendataan;

s. hidup secara mandiri dan dilibatkan dalam masyarakat;

t. berekspresi, berkomunikasi, dan memperoleh informasi;

u. berpindah tempat dan kewarganegaraan; dan

v. bebas dari tindakan Diskriminasi, penelantaran, penyiksaan, dan eksploitasi.

Ragam Penyandang Disabilitas meliputi:

a. Penyandang Disabilitas fisik;

b. Penyandang Disabilitas intelektual;

c. Penyandang Disabilitas mental; dan/atau

d. Penyandang Disabilitas sensorik.
Pasal 27 UU No. 8 tahun 2016 menjelaskan bahwa Pemerintah Daerah wajib melakukan perencanaan, penyelenggaraan, dan evaluasi tentang pelaksanaan Penghormatan, Pelindungan, dan Pemenuhan hak Penyandang Disabilitas. Peluang yang dapat diisi oleh kaum disabilitas dalam dunia kerja sebetulnya telah diamanatkan dalam peraturan perundang-Undangan. ${ }^{19}$

Bergulirnya semangat reformasi dan demokratisasi yang bertumpu pada penguatan sendi-sendi dasar hak asasi manusia (HAM), orang dengan disabilitas pada hakekatnya adalah makhluk sosial yang memiliki potensi, sehingga berpeluang untuk berkontribusi dan berperan secara optimal dalam segala aspek kehidupan berbangsa, bernegara dan bermasyarakat. ${ }^{20}$

Pemenuhan terhadap hak-hak disabilitas menjadi kewajiban Negara khususnya pemerintah, sebagaimana telah diatur dalam UU No.8 tahun 2016, bentuk konkritnya adalah Negara wajib memberikan kemudahan, perlakuan khusus, agar kaum disabilitas dapat memiliki penghasilan serta penghidupan yang layak. ${ }^{21}$

Henny mengatakan bahwa then one as the deciding factor in holding power is the norm or law. ${ }^{22}$ Oleh karena itu dalam pemenuhan Hak kesejahteraan sosial untuk Penyandang Disabilitas yang meliputi hak rehabilitasi sosial, jaminan sosial, pemberdayaan sosial, dan perlindungan sosial selain ditentukan oleh kesiapan pemerintah juga oleh stakeholder lainnya.

19 Abdul Latief Danu Aji1, Tiyas Nur Haryani, Diversitas dalam Dunia Kerja: Peluang dan Tantangan bagi Disabilitas, Spirit Publik Volume 12, Nomor 2, Oktober 2017, Hlm. 86.

20 Meilanny Budiarti Santoso, Nurliana Cipta Apsari, Pergeseran paradigma dalam disabilitas, Intermestic: Journal of International Studies Volume 1, No.2, Mei 2017, Hlm. 167.

21 http://ham.go.id/hak-aksesibilitas-bagipenyandang-disabilitas/

22 Henny Nuraeny \& Tanti Kirana Utami, The Victim Handling Model of Human Trafficking through Economic Independence, Vol. 16 No. 2 Mei 2016, FHUNSOED, Hlm. 121. 
Pemerintah dan Pemerintah Daerah wajib menjamin akses bagi Penyandang Disabilitas untuk mendapatkan rehabilitasi sosial, jaminan sosial, pemberdayaan sosial, dan perlindungan sosial.

Pasal 92 UU No. 8 Tahun 2016 menjelaskan bahwa:

1. Rehabilitasi sosial sebagaimana dimaksud dalam Pasal 91 diberikan oleh Pemerintah dan Pemerintah Daerah dalam bentuk:

a. motivasi dan diagnosis psikososial;

b. perawatan dan pengasuhan;

c. pelatihan vokasional dan pembinaan kewirausahaan;

d. bimbingan mental spiritual;

e. bimbingan fisik;

f. bimbingan sosial dan konseling psikososial;

g. pelayanan Aksesibilitas;

h. bantuan dan asistensi sosial;

i. bimbingan resosialisasi;

j. bimbingan lanjut; dan/atau

k. rujukan.

2. Rehabilitasi sosial sebagaimana dimaksud pada ayat (1) dilaksanakan secara persuasif, motivatif, dan koersif oleh keluarga, masyarakat, dan institusi sosial. 23

bahwa:

Selanjutnya dalam Pasal 93 ditegaskan

1. Jaminan sosial sebagaimana dimaksud dalam Pasal 91 diberikan oleh Pemerintah dan Pemerintah Daerah untuk Penyandang Disabilitas miskin atau yang tidak memiliki penghasilan.

2. Jaminan sosial sebagaimana dimaksud pada ayat (1) diberikan dalam bentuk asuransi kesejahteraan sosial, bantuan langsung berkelanjutan, dan bantuan khusus.

3. Bantuan khusus sebagaimana dimaksud pada ayat (2) mencakup pelatihan, konseling, perawatan sementara, atau bantuan lain yang berkaitan. ${ }^{24}$

23 UU No. 8 Tahun 2016 tentang penyandang disabilitas

24 Ibid
Pasal 94

1. Pemberdayaan sosial sebagaimana dimaksud dalam Pasal 91 dilakukan oleh Pemerintah dan Pemerintah Daerah melalui:

a. peningkatan kemauan dan kemampuan;

b. penggalian potensi dan sumber daya;

c. penggalian nilai dasar;

d. pemberian akses; dan/atau

e. pemberian bantuan usaha.

2. Pemberdayaan sosial sebagaimana dimaksud pada ayat (1) diberikan dalam bentuk:

a. diagnosis dan pemberian motivasi;

b. pelatihan dan pendampingan;

c. pemberian stimulan;

d. peningkatan akses pemasaran hasil usaha;

e. penguatan kelembagaan dan kemitraan; dan

f. bimbingan lanjut. 25

Perlindungan sosial dilakukan oleh Pemerintah dan Pemerintah Daerah melalui:

a. bantuan sosial;

b. advokasi sosial; dan/atau

c. bantuan hukum

Penyandang disabilitas di Kabupaten Cianjur mendapatkan berbagai program bantuan dari pemerintah, diantaranya:

1. BPJS kesehatan dan BPJS ketenagakerjaan

2. Kartu Indonesia Pintar (KIP)

3. Kartu Indonesia Sehat (KIS)

4. Kartu Keluarga Sejahtera (KKS)

5. Program Keluarga Harapan (PKH)

\section{KESIMPULAN}

Adapun kesimpulan dari penelitian ini adalah;

1. Kondisi penyandang disabilitas di Kabupaten Cianjur disebabkan karena sejak lahir, kecelakaan dan sakit dengan beragam disabilitas yang tersebar di beberapa kecamatan. Selanjutnya

${ }^{25}$ Ibid 
penyandang disabilitas yang sudah terdata oleh Dinas terkait sebagian besar termasuk keluarga miskin yang memerlukan berbagai program bantuan baik dari pemerintah maupun pihak swasta.

2. Bentuk perlindungan sosial bagi penyandang disabilitas di kabupaten Cianjur dilakukan dalam bentuk pemberian berbagai fasilitas dan jaminan sosial secara bertahap.

\section{SARAN}

1. Sebaiknya selain perlindungan sosial yang diberikan oleh pemerintah kepada penyandang disabilitas juga diberikan program pemberdayaan sosial sehingga bermanfaat untuk hidup lebih mandiri karena mempunyai keahlian dan keterampilan.

2. Diharapkan pendataan dan pemberian berbagai fasilitas dan jaminan sosial lebih dioptimalkan.

3. Diharapkan pemerintah daerah membuat peraturan daerah tentang perlindungan bagi penyandang disabilitas di Kabupaten Cianjur.

\section{DAFTAR PUSTAKA}

Arvian triantoro, menuju sinergitas penanggulangan kemiskina terpadu jawa barat 20182023, makalah disampaikan dalam kegiatan workshop penanggulangan kemiskinan , cianjur, 7 agustus 2018.

Ahmad hunaeny Zulkarnaen dan Tanti Kirana Utami, Perlindungan Hukum terhadap Pekerja dalam pelaksanaan Hubungan Industrial, PJIH vol. 3 nomor 2 tahun 2016.

Abdul Latief Danu Aji1, Tiyas Nur Haryani, Diversitas dalam Dunia Kerja: Peluang dan Tantangan bagi Disabilitas, Spirit Publik Volume 12, Nomor 2, Oktober 2017.

Henny nuraeny dan Tanti Kirana Utami, Legal Protection Against Children Who Are Victims Of Human Trafficking In Cianjur District Studied By Human Rights Perspective, Jurnal Dinamika Hukum ,Vol. 15 No. 2, May 2015.

Henny Nuraeny \& Tanti Kirana Utami, The Victim Handling Model of Human Trafficking through Economic Independence, Vol. 16 No. 2 Mei 2016, FH-UNSOED. DOI. 10.20884/1.jdh.2016.16.2.507.

http://ham.go.id/hak-aksesibilitas-bagi-penyandang-disabilitas/, diakses tanggal 15 Agustus 2018

Jazim Hamidi, Perlindungan Hukum terhadap Disabilitas dalam Memenuhi Hak Mendapatkan Pendidikan dan Pekerjaan Jurnal Hukum, IUS QUIA IUSTUM NO. 4 VOL. 23 OKTOBER 2016.

Jimly Asshiddiqie, Pengantar Ilmu Hukum Tata Negara Jilid 2, Sekretaris Jenderal dan Kepaniteraan Mahkamah Konstitusi, Jakarta, 2006.

Meilanny Budiarti Santoso, Nurliana Cipta Apsari, Pergeseran paradigma dalam disabilitas, Intermestic: Journal of International Studies Volume 1, No.2, Mei 2017. 
Rahayu Repindowaty Harahap dan Bustanuddin, Perlindungan Hukum Terhadap Penyandang Disabilitas Menurut Convention On The Rights Of Persons With Disabilities (CRPD) Jurnal Inovatif, Volume VIII Nomor I Januari 2015.

Zulkarnain Ridlwan, "Perlindungan Hak-hak Konstitusional Penyandang Disabilitas (Rights of Persons with Disabilities)", dimuat dalam Fiat Justitia Jurnal Ilmu Hukum, Volume 7 No. 2, Mei - Agustus 2013.

\section{Peraturan Perundang-undangan}

UUD 1945

UU No. 39 Tahun 1999 tentang Hak Asasi manusia

UU No,8 tahun 2016 tentang penyandang disabilitas 